http://nv.nltu.edu.ua

https://doi.org/10.15421/40280415

Article received $27.03 .2018 \mathrm{p}$.

Article accepted $26.04 .2018 \mathrm{p}$.

\title{
ТРАНСКОРДОННА СПІВПРАЦЯ УКРАЇНИ ТА ПОЛЫЩІ В ЕНЕРГЕТИЧНІЙ СФЕРІ
}

\begin{abstract}
Обгрунтовано теоретичні засади транскордонної співпраці країн у сучасних умовах. Основою для подальшого окреслення стратегічних напрямів розвитку співпраці визначено підходи, сформульовані у Європейській рамковій конвенції про транскордонне співробітництво між територіальними громадами. Розкрито зміст та особливості проектів, реалізованих у рамках транскордонної співпраці України і Польщі у сфері енергетики. Проведено SWOT-аналіз сильних та слабких сторін у транскордонному співробітництві між Україною та Польщею в енергетиці. Обгрунтовано потенційні можливості та загрози його розвитку у стратегічній перспективі. Аргументовано, що врахування окреслених на основі проведеного аналізу можливостей України й Польщі на базі використання сильних сторін має бути підгрунтям для налагодження українсько-польського співробітництва в енергетичній сфері у контексті нових його реалій після активізації євроінтеграції. Узагальнено чинні нормативно-правові основи транскордонної співпраці та визначено потенціал реалізації стратегій підвищення їі ефективності. Доведено, що важливим завданням для інтенсифікації транскордонної співпраці має бути активна співпраця між органами місцевої влади Польщі та України. Запропоновано напрями інституційно-організаційного забезпечення вирішення назрілих проблем та пріоритети стимулювання співпраці між Україною та Польщею в енергетичній сфері.
\end{abstract}

Ключові слова: транскордонна співпраця; енергетика; SWOT-аналіз; енергетична стратегія; інструменти фінансового стимулювання.

Вступ. Євроінтеграційні прагнення українського суспільства в умовах сьогодення актуалізують потреба вибудови ділових партнерських стосунків із країнамисусідами. Особливе значення у цьому контексті має транскордонна співпраця з Польщею, як однією із ключових і стратегічно важливих країн у східній Свропі. Водночас військові дії в Україні та пов'язана із цим соціально-економічна нестабільність зумовлюють нагальну потребу у співпраці в енергетичній сфері як основи гарантування економічної безпеки України у довготерміновій перспективі.

Аналіз останніх досліджень і публікацій. Проблеми транскордонної співпраці, зокрема, із Польщею, були предметом наукових пошуків вітчизняних та іноземних, у тому числі польських, фахівців. Їх досліджували такі учені, як: В. Будкін, Г. Горзелака, Л. Леуш, Г. Коваль, В. Кравців, Є. Макаренко, А. Міщук, Ю. Макогон, М. Мальський, Н. Мікула, М. Каспрзіка, О. Обухов, С. Писаренко, Д. Стрільчук, А. Федунь, М. Яворський та ін.

Однак імплементація угоди про Асоціацію із ЄС й нові реалії сучасної геополітики й особливості співробітництва у сфері енергетики у світі потребують подальшого обгрунтування адекватних і дієвих механізмів iii організації в Україні в частині співпраці на горизонтальному рівні з країнами-партнерами.

Постановка завдання. Метою роботи є обгрунтування організаційно-методичних основ транскордонного співробітництва України та Польщі в енергетичній сфері та стратегічних аспектів підвищення його ефективності в умовах євроінтеграції.
Викладення основного матеріалу. Незважаючи на стратегічну роль транскордонної співпраці у розвитку соціально-економічних відносин у Європі, потрібно зауважити, що у загальноєвропейській нормативно-правовій базі тривалий час не було спеціального акту, який регламентував би основи та принципи такого співробітництва. Цю прогалина у регулюванні транскордонної співпраці було усунуто після прийняття Свропейської рамкової конвенції про транскордонне співробітництво між територіальними громадами у Мадриді 21.05.1980 p., а також додаткового протоколу до неї у Страсбурзі, 9.11.1995 p. (Konventsiia, 2009). Також нормативно-правові основи для транскордонного співробітництва формують Європейська хартія місцевого самоврядування в частині регламентування права місцевих властей на свободу асоціацій та Декларація про транскордонне співробітництво в Європі. Водночас окремі статті щодо транскордонного співробітництву містяться у Європейській хартії регіональних мов і меншин, Декларації Асамблеї європейських регіонів щодо регіоналізму в Європі тощо.

У дослідженні теоретичною основою для подальшого обгрунтування стратегічних напрямів розвитку транскордонного співробітництва вважатимемо підходи, сформульовані у Європейській рамковій конвенції про транскордонне співробітництво між територіальними общинами або властями, у якій подано таку дефініцію транскордонного співробітництва: "...будь-які спільні дії, спрямовані на посилення та поглиблення добросусідських відносин між територіальними общинами або

\section{Інформація про авторів:}

Кочут Ірина Ігорівна, аспірант. Email: kochutiryn@gmail.com

Цитування за ДСтУ: Кочут І. І. Транскордонна співпраця України та Польщі в енергетичній сфері. Науковий вісник НлтУ України. Серія Економічна. 2018, т. 28, № 4. С. 83-87

Citation APA: Kochut, I. I. (2018). Transfrontal Collaboration of Ukraine and Poland in Energy Sphere. Scientific Bulletin of UNFU, 28(4), 83-87. https://doi.org/10.15421/40280415 
владами, що знаходяться під юрисдикцією двох або декількох Договірних Сторін, а також на укладання 3 цією метою будь-яких необхідних угод або досягнення домовленостей" (Konventsiia, 2009). Заважимо, що такої ж наукової позиції щодо розгляду теоретичного контексту поняття транскордонного співробітництва дотримуються, зокрема, М. Яворська (2011), аналізуючи безпосередньо українсько-польську транскордонну співпрацю, та В. Кравців (2016), вивчаючи проблеми розвитку транскордонного співробітництва України із країнамисусідами, в тому числі Польщею.

Інституційно-правовою основою реалізації програм транскордонного співробітництва в Україні на сьогодні, окрім міжнародних ратифікованих актів, $\epsilon$, зокрема, такі базові документи, як профільний закон "Про транскордонне співробітництво" (Zakon Ukrainy, 2010) та Державна стратегія регіонального розвитку на період до 2020 року (Stratehiia, 2014).
Аналіз стратегічних напрямів розвитку транскордонного співробітництва між Україною та Польщею у сфері енергетики передбачає потребу у початковому діагностуванні поточного його стану у контексті аналізу успішно реалізованих проектів ще до підписання Україною угоди про Асоціацію із СС, що має важливе значення з огляду на потреба ідентифікації ймовірних прорахунків у транскордонній співпраці в енергетичній сфері. У табл. 1 систематизовано ключові напрями співпраці у зазначеному секторі між Україною і Польщею (Enerhetyka, 2010).

Вважаємо доцільним провести SWOT-аналіз сильних та слабких сторін у транскордонній співпраці між Україною та Польщею у енергетичній сфері з наступною ідентифікацією потенціалу його розвитку та ймовірних загроз для обох країн (табл. 2 і 3).

Табл. 1. Проекти в межах транскордонної співпраці України і Польщі у сфері енергетики

\begin{tabular}{|c|c|c|}
\hline Назва проекту & $\begin{array}{l}\text { Вид транскордонно- } \\
\text { го співробітництва }\end{array}$ & Короткий зміст проекту \\
\hline $\begin{array}{c}\text { "Упровадження } \\
\text { енергозберігаючих } \\
\text { технологій для регіональ- } \\
\text { них органів влади" } \\
\end{array}$ & $\begin{array}{c}\text { У запровадженні } \\
\text { енергозберігаючих } \\
\text { технологій }\end{array}$ & $\begin{array}{c}\text { Реалізація польсько-українського проекту щодо впровадження енергоощад- } \\
\text { них технологій для органів влади на регіональних рівнях, відбувається у } \\
\text { Сумській області у частині модернізації, зокрема, об'єктів соціальної ін- } \\
\text { фраструктури. } \\
\end{array}$ \\
\hline $\begin{array}{c}\text { "Прокладання } \\
\text { газопроводу високого } \\
\text { тиску Сороки-Ямпіль" }\end{array}$ & $\begin{array}{l}\text { У будівництві та } \\
\text { модернізації } \\
\text { газопроводів }\end{array}$ & $\begin{array}{c}\text { Відібрано Міністерством економіки у } 2009 \text { р. для фінансування в межах } \\
\text { Державної програми розвитку транскордонного співробітництва в частині } \\
\text { підготовки відповідних проектів співпраці (загальний бюджет - 8,2 млн } \\
\text { грн). Одержав підтримку НАК "Нафтогаз України". Планове джерело фі- } \\
\text { нансування проекту - субвенції з держбюджету місцевим на здійснення за- } \\
\text { ходів із енергозбереження. } \\
\text {. }\end{array}$ \\
\hline $\begin{array}{c}\text { "Запровадження } \\
\text { відновлювальних } \\
\text { джерел енергії" }\end{array}$ & $\begin{array}{c}\text { У розвитку } \\
\text { нетрадиційних } \\
\text { джерел енергії }\end{array}$ & $\begin{array}{c}\text { Українсько-польський проект (спільна реалізація Люблінським воєводством } \\
\text { i Волинською областю), мета якого - використання відходів деревообробної } \\
\text { промисловості для виробницта брикетів, вирощування енергетичної лози, } \\
\text { збільшення площ під посіви ріпаку, виробництво біодизеля, біогазу, запро- } \\
\text { вадження нового енергоощадного обладнання (загалом висока енергетична } \\
\text { цінність біопалива та повна його відповідність євростандартам). }\end{array}$ \\
\hline
\end{tabular}

Джерело: узагальнено на основі: Офіційна сторінка Міністерства енергетики та вугільної промисловості України. - Режим доступу: http://mpe.kmu.gov.ua.

Табл. 2. Матриця SWOT-аналізу транскордонної співпраці між Україною та Польщею в енергетичній сфері (з позицій України)

\begin{tabular}{|c|c|}
\hline Сильні сторони & Слабкі сторони \\
\hline $\begin{array}{l}\text { • вигідне геополітичне розташування, значна протяжність кор- } \\
\text { донів; } \\
\text { • наявність достатньо розвиненої мережі пунктів пропуску; } \\
\text { • соціокультурні чинники та їх спорідненість з Польщею; } \\
\text { • сформоване транспортне, зокрема, автомобільне та залізнич- } \\
\text { не сполучення; } \\
\text { • } \text { значний транзитний потенціал для співпраці в енергетиці; } \\
\text { • налагоджені ділові стосунки між вітчизняними суб'єктами } \\
\text { господарювання та партнерами в Польщі. }\end{array}$ & $\begin{array}{l}\text { • бюрократичні перешкоди й проблеми низької кваліфікації } \\
\text { фахівців; } \\
\text { • дефіцит інструментів фінансового стимулювання розвитку } \\
\text { транскордонного співробітництва у галузі; } \\
\text { • низький рівень зацікавленості регіонів у співпраці з польсь- } \\
\text { кими партнерами; } \\
\text { • неефективність заходів із просування регіонів та їх марке- } \\
\text { тингового позиціонування; } \\
\text { • відсутність співпраці між науковцями та реальним бізнесом } \\
\text { у галузі; } \\
\text { - стримувальні чинники в частині наявності тіньових схем } \\
\text { розвитку бізнесу у сфері співпраці в енергетиці між обома } \\
\text { державами. }\end{array}$ \\
\hline Потенційні можливості & Загрози \\
\hline $\begin{array}{l}\text { • налагодження співпраці в енергетиці на засадах інтеграції в } \\
\text { межах системи "наука-інновації-бізнес"; } \\
\text { • будівництво додаткових пунктів пропуску через українсько- } \\
\text { польський кордон; } \\
\text { • подальше розширення транзитного потенціалу України; } \\
\text { • імплементація угоди про Асоціацію із ЄС та потенційний } \\
\text { вступ у ЄС як спосіб пропагування переваг транскордонного } \\
\text { співробітництва із Україною П Польщі; } \\
\text { • застосування механізму формування експертних груп для } \\
\text { дослідження потенціалу використання енергетичних можли- } \\
\text { востей України й Польщі для отримання взаємної вигоди; } \\
\text { • залучення альтернативних видів енергетики в контексті га- } \\
\text { рантування екологічної безпеки; }\end{array}$ & $\begin{array}{l}\text { • висока енергоємність вітчизняного виробництва та відсут- } \\
\text { ність стратегічних основ його модернізації у державі зага- } \\
\text { лом та на рівні регіональних програм розвитку транскордон- } \\
\text { ного співробітництва зокрема; } \\
\text { • залежність від імпорту сировини, електроенергії зокрема; } \\
\text { • дефіцит кваліфікованих кадрів у сфері енергетики в Україні } \\
\text { та слабкі позиції вітчизняних вишів щодо забезпечення їх } \\
\text { підготовки; } \\
\text { • неуніфікована нормативно-правова база розвитку енерге- } \\
\text { тичного сектору із відповідними стандартами у ЄС та Поль- } \\
\text { щі; } \\
\text { • низька якість енергетичної інфраструктури та ії невідповід- } \\
\text { ність вимогам сьогодення; }\end{array}$ \\
\hline
\end{tabular}


- в гармонізація вітчизняного законодавства у енергетичній сфері із загальноєвропейським;

- використання культурної спорідненості та близькості країн для розвитку їх співпраці.

Джерело: авторська розробка.

Табл. 3. Матриця SWOT-аналізу транскордонної співпраці між Україною та Польщею в енергетичній сфері (з позицій Польщі)

\begin{tabular}{|c|c|}
\hline Сильні сторони & Слабкі сторони \\
\hline $\begin{array}{l}\text { • значний транзитний потенціал для співпраці в енергетиці; } \\
\text { • соціокультурні чинники та їх спорідненість з Україною; } \\
\text { • вигідне геополітичне розташування, значна протяжність } \\
\text { кордонів; } \\
\text { • наявність достатньо розвиненої мережі пунктів пропуску; } \\
\text { • сформоване транспортне, зокрема, автомобільне та заліз- } \\
\text { ничне, сполучення; } \\
\text { • налагоджені ділові стосунки між суб'єктами господарюван- } \\
\text { ня та партнерами в Україні. }\end{array}$ & $\begin{array}{l}\text { • відтік кваліфікованої робочої сили у галузі з Польщі у Ні- } \\
\text { меччину й інші країни Свропи; } \\
\text { • недостатня зацікавленість прикордонних воєводств у роз- } \\
\text { витку транскордонного співробітництва; } \\
\text { • відсутність стимулів для місцевих органів влади у просу- } \\
\text { ванні проектів транскордонного співробітництва; } \\
\text { • намагання залучати вітчизняних науковців й інших фахівців } \\
\text { не як повноцінних бізнес-партнерів, а як дешевої робочої } \\
\text { сили у галузі. }\end{array}$ \\
\hline Потенційні можливості & Загрози \\
\hline $\begin{array}{l}\text { • "просування" ідеї активізації транскордонного співробіт- } \\
\text { ництва із Україною у контексті гарантування загальноєвро- } \\
\text { пейської енергетичної безпеки; } \\
\text { • налагодження співпраці в енергетиці на засадах інтеграції в } \\
\text { межах системи "наука-інновації-бізнес"; } \\
\text { • будівництво додаткових пунктів пропуску через українсь- } \\
\text { ко-польський кордон; } \\
\text { • розширення транзитного потенціалу Польщі; } \\
\text { • залучення експертів для аналізу потенціалу використання } \\
\text { енергетичних можливостей України для отримання вигоди } \\
\text { Польщею; } \\
\text { • використання альтернативних видів енергетики в контексті } \\
\text { підвищення рівня екологічної безпеки; } \\
\text { • посилення позицій Польщі у Свропейському Союзі як на- } \\
\text { дійного бізнес-партнера з урахуванням геополітичних тен- } \\
\text { денцій співпраці з Україною й зменшення в цьому контексті } \\
\text { впливу Росії на європейському енергетичному ринку. }\end{array}$ & $\begin{array}{l}\text { • недостатня ефективність регіональних програм розвитку } \\
\text { транскордонного співробітництва з Україною; } \\
\text { - проблеми фінансування розвитку енергетичної інфраструк- } \\
\text { тури Польщі, що звужує можливості для співпраці; } \\
\text { • дефіцит кваліфікованих кадрів у сфері енергетики в Поль- } \\
\text { щі; } \\
\text { - розбіжності у правовому регламентуванні розвитку енерге- } \\
\text { тичного сектору та постійний тиск ЄС, зокрема, у процесі } \\
\text { вибору векторів співпраці Польщі з потенційними партне- } \\
\text { рами на східному кордоні; } \\
\text { - проблеми у забезпеченні енергетичної безпеки у контексті } \\
\text { постійних змін політики Росії та загроз перебоїв в енерго- } \\
\text { постачанні; } \\
\text { відсутність стратегічних векторів розвитку транскордонно- } \\
\text { го співробітництва з Україною, як частини загальноєвро- } \\
\text { пейської стратегії розвитку енергетичного ринку Євро- } \\
\text { пейського Союзу. }\end{array}$ \\
\hline
\end{tabular}

Джерело: авторська розробка.

Врахування окреслених на основі проведеного аналізу (див. табл. 2 і 3) потенційних можливостей України й Польщі на базі максимального використання сильних сторін має бути підгрунтям для налагодження українсько-польського співробітництва в енергетичній сфері у контексті нових його реалій після початку активної інтеграції у СС у 2014 р., а також остаточної ратифікації угоди про Асоціацію країнами-членами СС у 2017 р., що розглянемо детальніше.

Виняткову важливість має етап євроінтеграції у сфеpi енергетики упродовж 2017-2018 рр. та власне транскордонної співпраці у цьому питанні із Польщею, без сприяння й використання енергетичної інфраструктури якої неможливе формування конкурентних переваг вітчизняних енергогенеруючих підприємств на європейському ринку. Тому доречною і значущою 3 огляду на перспективу є ухвалена уже після підписання угоди про Асоціацію Енергетична стратегія України на період до 2035 року "Безпека, енергоефективність, конкурентоспроможність" (Stratehiia, 2017). При цьому логічним та цілком обгрунтованим є розподіл їі етапів виконання на три підетапи, а саме: 1) до 2020 р.; 2) 2020-2025 рр.; 3) 2025-2035 pр. Досягнення ключових цілей на кожному з етапів передбачає реалізацію в тому числі низки проектів регіонального рівня.

Згадана стратегія передбачає, зокрема, на першому етапі остаточну імплементацію Третього енергетичного пакета, що дасть змогу створити повноцінні ринки природного газу й електроенергії згідно з енергетичним за- недостатній рівень безпеки на українському кордоні через вплив чинників соціально-політичної нестабільності та перманентних загроз, у тому числі енергетичної блокади, з боку Російської Федерації.

\section{меччину й інші країни Свропи;}

- недостатня зацікавленість прикордонних воєводств у розтранскордонного співробітництва;

ванні проектів транскордонного співробітництва;

намагання залучати вітчизняних науковців й інших фахівців не як повноцінних бізнес-партнерів, а як дешевої робочої

недостатня ефективність регіональних програм розвитку транскордонного співробітництва з Україною

щі проблеми у забезпеченні енергетичної безпеки у контекст постійних змін політики Росії та загроз перебоїв в енергопостачанні

го співробітництва з Україною, як частини загальноєвропейської стратегії розвитку енергетичного ринку Євро-

конодавством ЄС. При цьому заважимо, реалізується одне із стратегічних завдань для України в умовах ведення військових дій - це інтеграція в єдину європейську систему енергопостачання ENTSO-E, у разі успіху чого вдасться із використанням енергетичних мереж Польщі вивести вітчизняні ринки на принципово новий i якісно вищий рівень та зробити їх більш адаптованими до конкурентних засад розвитку, що дуже важливо для участі України у транскордонному співробітництві в ролі рівнозначного партнера.

На другому етапі (до 2025 р.) як пріоритетний вектор визначено інноваційний розвиток енергетичної інфраструктури, інтеграцію енергетичної системи України у загальноєвропейську (Stratehiia, 2017). Вважаємо, у перспективі це позитивно вплине на транскордонне співробітництво України та Польщі на засадах підвищення енергоефективності в умовах національної економіки, ідентифікації ключових об'єктів для реконструкції та нового будівництва в енергосфері, впровадження дієвих механізмів залучення інвестицій, оновлення енергетичної інфраструктури країни та Західного регіону (Львівської i Волинської областей зокрема), підвищення якості менеджменту загалом. У кінцевому підсумку це створить передумови для приєднання української енергосистеми до ENTSO-E в режимі експлуатації та повної інтеграції.

При цьому погоджуємось із думкою фахівців Міністерства енергетики та вугільної промисловості, що окремий значущий для національної економіки аспект 
транскордонної співпраці між Україною та Польщею це реалізація плану впровадження "розумних" енергетичних мереж (Smart Grids), результатом чого має бути розгалужена сучасна інфраструктура розвитку електротранспорту (Stratehiia, 2017). Адже саме метою третього етапу (до 2035 р.) Енергетичної стратегії України $є$ інноваційний розвиток енергетичного сектору на основі будівництва нової генерації, підвищення рівня конкуренції та упровадження смарт-технологій для вирівнювання піків споживання енергії.

Водночас транскордонне співробітництво України і Польщі у сфері енергетики сприятиме інтенсифікації інтеграційних процесів в Євросоюзі загалом, в тому числі шляхом здійснення регіональних проектів. Зокрема, у європейських країн існують ідеї спорудження так званих енергомостів до Литви з Польщі для постачання електроенергії, які, окрім економічної і стратегічної вигоди, також сприятимуть підвищенню конкурентоспроможності безпосередньо суб'єктів господарювання й економіки України, а також сприятимуть формуванню статусу країни у Європі як передового постачальника i транспортера енергетики (Stratehiia, 2017).

На наш погляд, особливе значення для успішного подальшого розвитку транскордонного співробітництва між Україною і Польщею у сфері енергетики й загалом у пріоритетних для обох країн секторах має обгрунтування відповідних стратегічних цілей такої співпраці у вітчизняній нормативно-правовій базі, прогрес у чому спостерігається упродовж останніх років.

Так, як позитивний аспект, потрібно відзначити, що для підвищення рівня конкурентоспроможності на світових ринках у 2016 р. було уточнено пріоритетні напрями розвитку науки і техніки 3 перспективою до 2020 р., серед яких (Zakon Ukrainy, 2016):

- фундаментальні наукові дослідження 3 найважливіших проблем розвитку науково-технічного, соціально-економічного, суспільно-політичного, людського потенціалу для забезпечення конкурентоспроможності України у світі та сталого розвитку суспільства і держави;

- інформаційні та комунікаційні технології;

- енергетика та енергоефективність;

- раціональне природокористування;

- нові речовини і матеріали.

Тобто згаданим Законом України "Про пріоритетні напрями розвитку науки і техніки" передбачають в тому числі й можливості застосування інструментів фінансової підтримки пріоритетних галузей i cфер, до яких віднесено енергетику та енергоефективність, що потрібно використати на практиці.

Водночас важливо, щоб поглиблення транскордонного співробітництва з Польщею відбувалось відповідно до ухваленої Україною Стратегії "Цифровий порядок денний" - 2020, в межах якої у контексті необхідності стимулювання пріоритетних галузей окреслено такі ключові напрями розвитку:

- освоєння нових технологій транспортування енергії, впровадження енергоефективних, ресурсоощадних технологій, освоєння альтернативних джерел енергії;

- освоєння нових технологій виробництва матеріалів, їх оброблення і з'єднання, створення індустрії наноматеріалів та нанотехнологій;

- розвиток сучасних інформаційних і комунікаційних технологій (Proekt, 2010).
Водночас, Законом України "Про пріоритетні напрями інноваційної діяльності в Україні" (Zakon Ukrainy, 2011) до останніх також віднесено сферу енергетики.

На наш погляд, саме інституційно-організаційне забезпечення вирішення стратегічних проблем у співпраці в енергетичній сфері між Україною та Польщею на основі визначення пріоритетності цього у згаданих законах України сприятиме її поглибленню й гарантуванню енергетичної безпеки країни в кінцевому підсумку. Також вважаємо за доцільне запропонувати внести у зазначені нормативно-правові акти, першочергово у Закон України "Про пріоритетні напрями інноваційної діяльності в Україні" приписи щодо визначення пріоритетної співпраці між двома країнами у енергетичній сфері. При цьому також, на нашу думку, доцільно було б внести зміни у Митний та Податковий кодекси України в частині передбачення можливості надання податкових пільг, а також скасування мита у разі імпорту високотехнологічного обладнання, що використовуватиметься у процесі модернізації вітчизняної енергетичної системи чи скеровуватиметься на реалізацію конкретних проектів співпраці між Україною та Польщею. Саме ці важелі фінансового стимулювання сприяли б активізації співробітництва й одночасному вирішенню енергетичних проблем національної економіки.

Ще одне стратегічно важливе завдання у сфері транскордонної співпраці мало б полягати в активній співпраці із органами місцевої влади Польщі та України загалом, а також в контексті розширення зв'язків із окремими воєводствами для вироблення спільних механізмів сприяння підвищенню енергетичної безпеки України завдяки відповідним ресурсам та преференціям, якими володіє Польща як країна-член ЄС.

Висновки і перспективи подалыших розвідок. Транскордонне співробітництво у реаліях глобалізованого світу є основою для реалізації конкурентних переваг сторін співпраці на взаємовигідних засадах, що особливо важливо на сучасному етапі реформування національної економіки. У цьому контексті зростає роль у налагодженні довготривалих партнерських стосунків із Польщею, як геополітичним союзником та однією із передових економік східної Європи.

Транскордонне співробітництво України та Польщі повинно здійснюватись 3 дотриманням принципу наукової обгрунтованості державної політики на основі підвищення енергоефективності економіки України, визначення об'єктів для реконструкції та нового будівництва в енергетичній сфері, застосування фінансових інструментів залучення інвестицій для оновлення енергетичної інфраструктури, розвитку менеджменту в галузі.

Енергетична стратегія України має стати підгрунтям реалізації заходів із виведення вітчизняних ринків на новий якісно вищий рівень на умовах паритетної співпраці із енергетичними мережами Польщі, адаптувавши їх до євростандартів шляхом забезпечення можливості участі України у транскордонному співробітництві як рівнозначного та стратегічно важливого енергетичного союзника. Водночас сформульовані пропозиції повинні сприяти зростанню енергетичної безпеки та незалежності як України і Польщі, так і інших країн СС. 


\section{Перелік використаних джерел:}

Enerhetyka. (2010). Ofitsiina storinka Ministerstva enerhetyky ta vuhilnoi promyslovosti Ukrainy. Retrieved from: http://mpe.kmu.gov.ua. [In Ukrainian].

Konventsiia. (2009). Yevropeiska ramkova konventsiia pro transkordonne spivrobitnytstvo mizh terytorialnymy obshchynamy abo vlastiamy (Postanova Verkhovnoi Rady Ukrainy pro pryiednannia do konventsii vid 16.11.2009 r.). Retrieved from: http://zakon2.rada.gov.ua/laws/show/995_106. [In Ukrainian].

Kravtsiv, V. S. (Ed.). (2016). Rozvytok transkordonnoho spivrobitnytstva: naukovo-analitychna dopovid / NAN Ukrainy. DU "Instytut rehionalnykh doslidzhen imeni M. I. Dolishnoho NAN Ukrainy"; Lviv. 25 p. (Seriia "Problemy rehionalnoho rozvytku"). [In Ukrainian].

Proekt. (2010). Tsyfrova adzhenda Ukrainy - 2020 ("Tsyfrovyi poriadok dennyi" - 2020). Kontseptualni zasady, pershocherhovi sfery, initsiatyvy, proekty "tsyfrovizatsii" Ukrainy do 2020 roku. Retrieved from: https://ucci.org.ua/uploads/files/58e78ee3c3922.pdf. [In Ukrainian].

Stratehiia. (2014). Derzhavna stratehiia rehionalnoho rozvytku na period do 2020 roku. Ofitsiinyi visnyk Ukrainy, 70, 23-25. [In Ukrainian].
Stratehiia. (2017). Enerhetychna stratehiia Ukrainy na period do 2035 roku "Bezpeka, enerhoefektyvnist, konkurentospromozhnist" (skhvalena rozporiadzhenniam Kabinetu Ministriv Ukrainy vid 18.08.2017 r., № 605-r). Retrieved from: http://mpe.kmu.gov.ua/minugol/control/publish/article?art_id=245234085. [In Ukrainian].

Yavorskyi, M. S. (2011). Ukrainsko-polska transkordonna spivpratsia u sferi pidtrymky innovatsii ta enerhozberezhennia. Nauka ta innovatsii, 2, 73-76. [In Ukrainian].

Zakon Ukrainy. (2010). "Pro vnesennia zmin do Zakonu Ukrainy "Pro transkordonne spivrobitnytstvo". Zakon Ukrainy № 3715-VI vid 21.01.2010 r. Retrieved from: http://zakon0.rada.gov.ua. [In Ukrainian].

Zakon Ukrainy. (2011). "Pro priorytetni napriamy innovatsiinoi diialnosti v Ukraini". Zakon Ukrainy № 3715-VI vid 08.09.2011 r. (zi zminamy i dopovnenniamy). Retrieved from: http://zakon3.rada.gov.ua/laws/show/3715-17. [In Ukrainian].

Zakon Ukrainy. (2016). "Pro priorytetni napriamy rozvytku nauky i tekhniky". Zakon Ukrainy № 2623-14 vid 16.01.2016 r. Retrieved from: http://zakon3.rada.gov.ua/laws/show/2623-14. [In Ukrainian].

\section{Львовский национальный университет им. Ивана Франко, г. Львов, Украина}

\section{ТРАНСГРАНИЧНОЕ СОТРУДНИЧЕСТВО УКРАИНЫ И ПОЛЬШИ В ЭНЕРГЕТИЧЕСКОЙ СФЕРЕ}

Обоснованы теоретические основы трансграничного сотрудничества стран в современных условиях. Основой для дальнейшего определения стратегических направлений развития сотрудничества определены подходы, сформулированные в Европейской рамочной конвенции о приграничном сотрудничестве территориальных сообществ. Раскрыты содержание и особенности проектов, реализуемых в рамках трансграничного сотрудничества Украины и Польши в сфере энергетики. Проведен SWOT-анализ сильных и слабых сторон в трансграничном сотрудничестве между Украиной и Польшей в энергетике. Обоснованны потенциальные возможности и угрозы его развития в стратегической перспективе. Аргументировано, что учет определенных на основе проведенного анализа возможностей Украины и Польши на базе использования сильных сторон должен быть основой для налаживания украинско-польского сотрудничества в энергетической сфере в контексте новых его реалий после активизации евроинтеграции. Обобщены существующие нормативно-правовые основы трансграничного сотрудничества и определен потенциал реализации стратегий повышения ее эффективности. Доказано, что важной задачей для интенсификации трансграничного сотрудничества должно быть активное сотрудничество между органами местной власти Польши и Украины. Предложены направления институционально-организационного обеспечения решения существующих проблем и приоритеты стимулирования сотрудничества между Украиной и Польшей в энергетической сфере.

Ключевые слова: трансграничное сотрудничество; энергетика; SWOT-анализ; энергетическая стратегия; инструменты финансового стимулирования.

I. I. Kochut

Ivan Franko National University of Lviv, Lviv, Ukraine

\section{TRANSFRONTAL COLLABORATION OF UKRAINE AND POLAND IN ENERGY SPHERE}

The theoretical bases and practical aspects of the countries transfrontal collaboration in modern terms are justified. In order to achieve the purpose and objectives of the research, general scientific and special methods of academic research, in particular, analysis and synthesis, induction and deduction, comparison, abstraction, modern modeling methods are applied. Maintenance and features of the projects realized within the framework of transfrontal collaboration of Ukraine and Poland in the sphere of energy are exposed. We conducted the SWOT- analysis of strengths and weaknesses in a transfrontal collaboration between Ukraine and Poland in energy sphere. Potential possibilities and threats of its development in a strategic prospect are identified. We specified generalized existent normatively-legal bases of transfrontal collaboration and potential of implementation of existent strategies of its efficiency increase. Directions of the institutionally-organizational providing of decision of strategic problems in collaboration in energy sphere between Ukraine and Poland are offered. The transfrontal collaboration of Ukraine and Poland are to come true from inhibition of principle of scientific public policy on principles of increase of Ukrainian economy energy efficiency, determination of objects for reconstruction and new building in energy sphere, application of financial instruments of investments bringing in for energy infrastructure updating, and development of management. It is well-proven that energy strategy of Ukraine must become soil of that on the terms of parity collaboration with the energy circuits of Poland to show out home markets on a new and qualitatively higher level. The suggestions set must promote to the increase of energy strength and independence as Ukraine and Poland and other countries of the European Union. Prospects for the latest scientific research are the study of priorities of transfrontal collaboration between Ukraine and neighbouring countries in the context of finding a balanced model of cooperation considering European integration and globalization trends.

Keywords: transfrontal collaboration; power engineering; SWOT-analysis; energy strategy; instruments of financial stimulation. 